\title{
Entry Qualification, Pre-Admission Performance, English Proficiency and Performance of Bachelor of Arts (Hons) in Accounting and Finance Students
}

\author{
Norbaizura Hamid $^{1, *}$, Norashikin Ismail ${ }^{2}$, RoszanaTapsir ${ }^{2}$ \\ ${ }^{1}$ Kolej Poly-Tech MARA, Selangor, Malaysia \\ ${ }^{2}$ Faculty of Accountancy, Universiti Teknologi MARA, Malaysia
}

Received September 7, 2019; Revised October 10, 2019; Accepted October 17, 2019

Copyright@2019 by authors, all rights reserved. Authors agree that this article remains permanently open access under the terms of the Creative Commons Attribution License 4.0 International License

\begin{abstract}
This paper examines different factors which affect the academic performance of students of the Bachelor of Arts (Honours) in Accounting and Finance (BAAF) at Kolej Poly-Tech Mara, Bangi. The study provides insights into the association between different entry qualifications and academic outcomes, complementing the evidence that advocates the implementation of academic merit for admission. This paper expands this evidence base by examining relationships between entry qualification, a pre-degree academic performance used for admission, and performance at the BAAF programme conducted in Malaysia. Regression results showed that the student's CGPA for entry, English proficiency (MUET) and entry qualification were significant factors for the academic performance in the BAAF programme at the $1 \%$ level. Comparing the academic performance of two different entry qualifications, the result of independent t-test shows that students who enter with Diploma from UiTM performed better than the students who graduated with a Diploma from Kolej Poly-Tech MARA. This study only focuses on BAAF students at Kolej Poly-Tech Mara, Bangi. Thus, the findings are specific to the conditions at this college and are not generalisable. A similar study could be done at other colleges and universities so that comparisons and generalisations could be derived. The results of this study have several implications for university administrators and policymakers. It justifies setting the requirement for entry. The results show that the same minimum point system of entry can be unfair to students from different entry qualifications. Furthermore, the minimum grade point required (min CGPA) for entry must consider the entire curriculum of the qualification used for entry.
\end{abstract}

Keywords Entry Qualification, Academic
Performance, English Proficiency, Bachelor of Accounting, Gender

\section{Introduction}

The academic achievement of graduates is perhaps the primary goal of universities or higher education institutions. It can be measured from multiple aspects such as students' achievements in the final exams of each semester, CGPA per semester, Average Grade Value (GPA) for each semester or score for a specific subject. Besides that, academic performance is based on performance in tests, coursework and examinations of undergraduate students where the indicator of the overall performance is based on the Grade Point Average (GPA). Discovering the factors that influence the academic success of students is vital to institutions, students and parents as they entail implications for admission, sponsorship policies, and teaching strategies.

This research is concerned with student performance in the Bachelor in accounting and finance of Ireland University in Malaysia. The Bachelor of Arts (Hons) in accounting and finance (BAAF) is a franchise programme of Dublin Business School, Ireland conducted as a franchise degree programme in Kolej Polytech MARA (KPTM), a private higher institution in Malaysia. The programme is accredited by the Malaysian Qualifying Agency and receives the same number of paper exemptions as other local degrees in accounting from a well-established public university in Malaysia from the professional body the Association of Chartered Certified Accountant (ACCA). In terms of the duration of the study, the programme takes three years for admission with 
matriculation/Malaysian Higher School Certificate (STPM) and two years for admission with Diploma in accounting from a recognised public or private higher institution in Malaysia. The first batch of students graduated in 2017. Since the programme is offered for the first time not only in KPTM but in Malaysia, we study the factors influencing student performance. Understanding the factors associated with performance is crucial, particularly when the students need to pay considerably high fees for an overseas degree.

Empirical evidence provides support for the significant association between academic performance used for admission and the performance of students inthe bachelor degree programme. Past performance may indicate commitment, diligent and intellectual level of students. Tho (1994), for example, found that pre-admission qualification influence students' performance at a higher level and high overall academic ability have better opportunities to perform well. Studies also provide evidence that students who entered the university with better scores in their high school exams achieved higher grades in their undergraduate programmes (Islam, 2014; Ladan, Adeshina, and Udoh, 2015; Rajandran et al., 2014).

The present study provides insights into the association between different entry qualifications and academic outcomes, complementing the evidence that advocates the implementation of academic merit for admission. This paper seeks to expand this evidence base by examining relationships between entry qualification, a pre-degree academic performance used for admission, and performance at the BAAF programme conducted in Malaysia.

\section{Literature Review and Hypotheses Development}

This study examines the factors that contribute to the academic performance of students enrolled in the Bachelor of Art (Honours) in Accounting and Finance (BAAF) programme which is a collaboration between KPTM and Dublin Business School. The dependent variable is the student academic performance measured as the overall marks scored at graduation. The study will also examine whether different pre-university qualifications (entry qualification) used for admission have a significant relationship with academic performance.

\subsection{Pre-university Academic Performance}

Studies have shown that there is a positive relationship between high school or pre-university performance and the performance of undergraduates. Students who entered the university with better scores in their high school exams achieved higher grades in their undergraduate programmes (Islam, 2014; Ladan, Adeshina, and Udoh, 2015; Soto and Anand, 2009; James, Reem, Shyamala, and Sharada,
2014;Garkaz et al., 2011; Rajandran et al., 2014). One conclusion is that the students with higher GPAs had previously developed better study skills and habits that prepared them for conceptual learning, data analyses, and research-based problem solving, and as a consequence were able to depend less on teacher-driven instruction at the university. Ladan, Adeshina \& Udoh (2015) found that students with good grades in accounting at secondary school achieved excellent results when they pursue their higher studies. Rajandran et al. (2014) found that CGPA at entry was the most influential factor affecting academic performance. Similarly, James, Reem, Shyamala \& Sharada (2014) found that CGPA entry is a good predictor of student achievement in physiology.

However, contradictory results were also found where a high CGPA or good result does not necessarily have a positive relationship with the performance of undergraduate students. Some of them were also likely to drop out (Abdulrahman and Al-Mazrou, 2008). Moreover, some studies found no relationship between the pre-qualification requirement and academic performance, such as Abisuga, Olanrewaju, and Oyekanmi (2015).

Given the above background, the following hypothesis is developed:

$\mathrm{H}_{1}$ : The higher the CGPA at the entry point, the better the academic performance of BAAF students.

\subsection{Entry Qualification}

Admission for accounting students covered by this study is divided into two categories. The first group of students enters the program based on their diploma in accounting qualification and the second group is from pre-university foundation program or matriculation qualification. The group from diploma in accounting have spent three years in university to complete their diploma while matriculation program, students spent only one year in colleges. Therefore, candidates with matriculation certificates (Matrics) will enter the degree program in year one and will take three years to complete. On the other hand, those with a diploma in accounting will come the degree in year two and will take only two years to complete their degree. Students from a diploma in accounting would have learnt more accounting and business-related at their diploma program in comparison to students at the matriculation program. Therefore, students from diploma are expected to be more analytical and perform better in their accounting degree courses. Therefore, based on the above, the following hypothesis is developed:

$\mathrm{H}_{2}$ : Students from Diploma in accounting perform are better than others in the BAAF programme.

\subsection{English Proficiency}

For many countries, including Malaysia, English is the second language and is a compulsory subject in the 
Malaysia Education Certificate (SPM). English is also one of the conditions for registration at Malaysian public and private universities where candidates are required to sit for the MUET (Malaysian University English Test). The Higher Education Ministry of Malaysia (now, Education Ministry) encourages all universities in Malaysia to use English as the teaching medium. English is emphasised in the teaching at public universities in Malaysia, and as such, the ability to understand what is presented during academic lectures is an essential skill required by graduates.

The literature shows that there is a positive relationship between English proficiency and undergraduate students' performance. English-speaking students have a high average GPA compared to those who are trained in other languages and those students who entered with higher scores for their pre-entry English requirement achieved higher CGPA than those with lower scores (Ghenghesh, 2014; AlMously, Salem \& AlHamdan, 2013; Rethinasamy \& Chuah, 2011; Buniyamin, Kassim \& Mat, 2015;Sahragard, Baharloo, Yen \& Kuzma, 2009). At the high school level of education, the same can be said about English proficiency and students' performance, namely that there is a significant relationship between English language proficiency and academic achievements at high school (Millie, Racca \& Lasaten, 2016).

In Malaysia, university applicants are required to sit for the Malaysian University English Entry (MUET) examination as a pre-requisite to entering university. The score (band) that they have to achieve would depend on the programmes that they are applying for. Generally, Science and Technology programmes, and Law and Accountancy programmes require a higher band. Studies have shown that undergraduate students at Malaysian universities scoring higher bands in MUET perform better than those who scored lower bands (MohdNopiah, Ismail, Khatimin, Abdullah\& Mustafa, 2011; Rahmat, Min, Sungif\&Yusup, 2015). A similar positive relationship was found in studies examining English proficiency and postgraduate students' performance (Kumar, 2014).

Nopiah et al. (2011) indicated that MUET has a high correlation to academic performance and a good command of English in the entry level can influence students' academic performance during later years in university as indicated in the CGPA improvement analysis. Othman \&Nordin (2013) and Rahmat et al. (2015) found that there was a medium positive correlation between the undergraduates' English language proficiency and academic achievements. It means that undergraduate students who are more proficient in English achieved higher academic achievement.

Yen \&Kuzma (2009) found that students who obtained low scores during IELTS have a higher possibility of having poor academic performance. Woodrow (2006) showed that English language proficiency, as measured by IELTS is moderately predictive of academic achievement in the first semester students.
Therefore, the following hypothesis is developed:

H3: The higher the English proficiency (MUET) scores, the better the academic performance of BAAF students.

\subsection{Gender}

There is a significant difference between male and female concerning their academic performance because females, on average, achieve higher academic performance than males (Sheard, 2009, Garkaz, Banimahd, and Esmaeili, 2011; Jayanthi et al., 2014, Zainal et al., 2014; Eze, Ezenwafor, and Obidile, 2016). This is due to the fact that female students are more committed to their studies than male students (Sheard, 2009).

However, contrasting results were found in certain study areas. Sam (2016) found that male students studying financial accounting had higher scores and better results than female students. Also, mixed results were found at high school levels. Kyei \& Apam (2011) found that male students were performing better than the female students in senior high school mathematics examination in the Upper East region of Ghana. Oppong (2013) found that female students scored better than their male counterparts in essay tests, while male students obtained better marks than their female friends when answering multiple choice questions for high school history. Sam (2016) found that gender influences students' performance in financial accounting and plays a crucial role in determining the level of academic performance. Zainal et al. (2014) described that there were statistically significant differences between female and male students in academic performance. Jayanthi et al. (2014) found that the coefficient of female students is highly significant in quality of academic performance regarding gender. Also, Garkaz, Banimahd, and Esmaeili (2011) found that there is a significant difference between male and female concerning their academic performance where females, on average, achieve higher academic achievement than male. Thus, the following hypothesis is developed:

$\mathrm{H}_{4}$ : Female students in BAAF record significantly better academic performance than male students.

The hypotheses developed in this study are tested using regression analysis. The model examines the association between the dependent variable of academic performance among the student and the independent variables of CGPA entry, entry qualification, English proficiency and gender as follows:

$$
\begin{gathered}
\text { ACP }=\alpha+\beta_{1} \text { CGPA ENTRY }+\beta_{2} \text { ENTRY } \\
\text { QUALIFICATION }+\beta_{3} \text { ENGLISH } \\
\text { PROFICIENCY(MUET) }+\beta_{4} \text { GENDER }+\varepsilon_{\mathrm{i}}
\end{gathered}
$$

Where:

ACP = Academic performance of the students measured in terms of raw marks in percentage obtained by the students at the end of their Bachelor degree programme

CGPA entry = CGPA entry represented by cumulative grade point average earned by the students during Diploma, 
matriculation or STPM results

ENTRY QUALIFICATION = A dummy variable with a value of 1 if a student from Diploma qualification and 0 if a student from STPM and matriculation

ENGLISH PROFICIENCY $($ MUET) $=$ English MUET represented by band score of students before they enrol this programme. Band scores are band 1 , band 2 , band 3 , band 4 , band 5 and the last is band 6 . The higher is the band, the higher their English proficiency

GENDER = A dummy variable with a value of 1 if female students and 0 if a male student

$\beta_{\mathrm{i}}=$ The coefficients of independent variables

$\varepsilon_{i}=$ Error term

\section{Research Methodology}

A questionnaire was used to collect the student's demographic profile data. The questionnaire consisted of two sections. The first section contained questions relating to their demographic profile. The second section contained questions for information regarding the results of their pre-university programme. They are also required to write their student number for us to match with the academic performance of their BAAF programme at graduation. Data on the academic performance of the students is measured in terms of their raw marks in percentage at the end of their Bachelor degree programme. It is obtained with permission from the Dublin Business School Moodle system in KPTM.

There is a total of 120 final year students from two different admission pathways during the period of study. The study distributed 120 questionnaires to all the graduating students. The questionnaires were administered voluntarily and were filled in by all final year students.

Table 1 shows the statistics of students included in the analysis by gender. Out of the 120 students, 87 (72.5\%) students were female, while 33 (27.5\%) were male.

Table 1. Percentage of respondent by gender

\begin{tabular}{|c|c|c|}
\hline Gender & Number of students & Percent (\%) \\
\hline MALE & 33 & 27.5 \\
\hline FEMALE & 87 & 72.5 \\
\hline Total & 120 & 100.0 \\
\hline
\end{tabular}

Table 2 shows the respondents' qualification used for admission to the BAAF programme.

Table 2 shows that 95 students (79.2\%) were admitted into the BAAF programme using their Diploma, while only 25 students (20.8\%) were admitted based on their Malaysian Higher School Certificate (STPM) or matriculation.

Table 2. Entry qualification for admission to the BAAF programme

\begin{tabular}{|c|c|c|}
\hline Academic Qualification & $\begin{array}{c}\text { Number of } \\
\text { Students }\end{array}$ & $\begin{array}{c}\text { Percent } \\
\text { (\%) }\end{array}$ \\
\hline Diploma in Accounting & 95 & 79.2 \\
\hline $\begin{array}{c}\text { Malaysian Higher School Certificate } \\
\text { (STPM)/ Matriculation }\end{array}$ & 25 & 20.8 \\
\hline Total & 120 & 100.0 \\
\hline
\end{tabular}

In terms of academic performance for admission, Table 3 shows slightly more than half of the students (55.8\%) were admitted with a CGPA above 3.0, and another $44.2 \%$ were admitted based on the CGPA between 2.5 to 2.99 . The minimum CGPA required is 2.50 .

Table 3. CGPA admission based on qualification

\begin{tabular}{|c|c|c|c|}
\hline \multirow{2}{*}{ CGPA } & \multicolumn{2}{|c|}{ Qualification } & \multirow{2}{*}{ Total Students } \\
\cline { 2 - 3 } & Diploma & STPM/Matriculation & \\
\hline $3.50-4.00$ & 25 & 2 & 22.5 \\
\hline $3.00-3.49$ & 29 & 11 & 33.3 \\
\hline $2.50-2.99$ & 41 & 12 & 44.2 \\
\hline Total & 95 & 25 & 100.0 \\
\hline
\end{tabular}

Other than a minimum CGPA, students must also pass MUET with a minimum score of band 2. Table 4 shows the number of students classified according to MUET examination band score. Fifty-eight students scored band 2 (48.3\%), another 40 (33.33\%) admitted with band 3, and the balance of 27 students (22.5\%) scored band 4 . The higher the MUET band scored, the higher their English proficiency level.

Table 4. Student's English MUET band score

\begin{tabular}{|c|c|c|}
\hline Band Score & Number of students & Percent (\%) \\
\hline 2 & 58 & 48.3 \\
\hline 3 & 49 & 40.8 \\
\hline 4 & 13 & 10.8 \\
\hline Total & 120 & 100.0 \\
\hline
\end{tabular}

\section{Results and Discussion}

Table 5 presents the descriptive statistics comparing students' performance based on their admission pathway. 
Table 5. Descriptive statistics comparing the performance of students from Diploma and Matriculation/STPM

\begin{tabular}{|c|c|c|c|c|c|c|c|c|c|c|}
\hline & \multicolumn{4}{|c|}{ Admission with Diploma (n = 95) } & \multicolumn{5}{c|}{ Admission with STPM/matriculation } \\
\hline & Mean & Med & SD & Min & Max & Mean & Med & SD & Min & Max \\
\hline CGPA Entry & 3.15 & 3.23 & 0.37 & 2.50 & 3.86 & 2.99 & 3.00 & 0.40 & 2.50 & 3.75 \\
\hline $\begin{array}{c}\text { Proficiency } \\
\text { English(MUET) }\end{array}$ & 2.71 & 3.00 & 0.70 & 2 & 4 & 2.32 & 2 & 0.48 & 2 & 3 \\
\hline $\begin{array}{c}\text { Academic Performance } \\
\text { (Final overall marks of } \\
\text { BAAF) }\end{array}$ & 62.96 & 63 & 6.57 & 47.61 & 75.77 & 55.49 & 56.33 & 8.53 & 40 & 72 \\
\hline
\end{tabular}

Table 5 showed that Diploma students entered the programme with higher CGPA (mean 3.15) and English proficiency (mean MUET band 2.71) in comparison to students admitted with STPM/Matriculation (mean CGPA 2.99 and MUET 2.32 respectively). The average MUET score for Diploma students is 2.75, with the highest score of band 4 and the lowest score of band 2. The performance results in their Bachelor degree programme (BAAF) shows that students from the Diploma programme graduated the BAAF programme with a final overall mark of $62.96 \%$. They obtained higher overall marks than the students who were admitted with STPM/Matriculation and graduated with a mean score of 55.49\%.

An independent sample t-test was conducted in order to see if the difference in final overall marks between the two groups of students is significant. Table 6 presents the result of independent $t$-statistics comparing the results of two different groups based on admission pathway.

Table 6. Independent t-test on the difference in BAAF academic performance between Diploma entry and SPM/Matriculation entry

\begin{tabular}{|c|c|c|c|c|c|}
\hline Entry Qualification & $\mathrm{n}$ & Mean & SD & t-stats & p-value \\
\hline STPM / Matriculation & 25 & 55.49 & 8.55 & -4.732 & $.000^{* * *}$ \\
\hline Diploma & 95 & 62.96 & 6.57 & & \\
\hline
\end{tabular}

*** Significance at the $1 \%$ level

The result shows that students admitted from Diploma performed significantly better than students who entered the program from STPM or matriculation colleges at the $1 \%$ level $(\mathrm{t}=-4.732$, $\mathrm{p}=0.000)$.

The students who entered from Diploma came from two different higher learning institutions, namely Universiti Teknologi MARA (UiTM) and Kolej Polytech MARA (KPTM). Table 7 presents the descriptive statistics of the two groups of students.

Table 7 shows that students who entered the BAAF program from UiTM, in general, enter BAFF with a lower CGPA in comparison to students with Diploma from KPTM. The mean CGPA entry of Diploma students from UiTM is 2.96 while the mean CGPA of Diploma students from KPTM is 3.27. In terms of English language proficiency, the result shows that Diploma students from UiTM recorded a mean score of 2.78 while KPTM students' mean score for MUET is 2.66. The results of these two groups are shown as academic performance measured as overall marks scored in the BAAF program.

Table 8 presents the results comparing these two groups of students.

The result shows that students who entered the BAAF programme with Diploma from UiTM performed better with a final overall mark of $64.92 \%$ in comparison to students with Diploma from KPTM who graduated with an average final mark of $61.71 \%$. The results are significant at the $5 \%$ level $(t=-2,376, p=0.020)$. The results explained that even though students with Diploma UiTM enter the degree programme with a lower CGPA, they performed better in BAAF compared to BAAF students with a Diploma from KPTM. The results perhaps can be explained by the fact that students who joined UiTM to do Diploma in accounting have better Malaysia Education Certificate (SPM) results compared to students who joined KPTM after their SPM. The lower CGPA obtained by students at their Diploma in UiTM may be due to the differences in the programme curriculum. Therefore, given that curriculum is more comprehensive, despite the lower CGPA, they still perform better in the BAAF programme than students with higher CGPA from KPTM. 
Entry Qualification, Pre-Admission Performance, English Proficiency and

Performance of Bachelor of Arts (Hons) in Accounting and Finance Students

Table 7. Comparing results of two different groups of students from Diploma qualification

\begin{tabular}{|c|c|c|c|c|c|c|c|c|c|c|}
\hline & \multicolumn{4}{|c|}{ Diploma UiTM (n= 37) } & \multicolumn{5}{c|}{ Diploma KPTM (n = 58) } \\
\hline & Mean & Med & SD & Min & Max & Mean & Med & SD & Min & Max \\
\hline CGPA Entry & 2.96 & 2.90 & 0.28 & 2.50 & 3.61 & 3.27 & 3.33 & 0.37 & 2.50 & 3.86 \\
\hline $\begin{array}{c}\text { Proficiency } \\
\text { English(MUET) }\end{array}$ & 2.78 & 3 & 0.67 & 2 & 4 & 2.66 & 3 & 0.72 & 2 & 4 \\
\hline $\begin{array}{c}\text { Academic Performance } \\
\text { (Final overall marks of } \\
\text { BAAF program) }\end{array}$ & 64.92 & 64.47 & 5.69 & 54.87 & 75.77 & 61.71 & 61.46 & 6.84 & 47.61 & 73.71 \\
\hline
\end{tabular}

Table 8. Independent t-test on the difference in BAAF academic performance between Diploma KPTM and Diploma UiTM

\begin{tabular}{|c|c|c|c|c|c|}
\hline Entry Qualification & $\mathrm{N}$ & Mean & $\mathrm{SD}$ & $\mathrm{t}$ & P-value \\
\hline Diploma KPTM & 58 & 61.71 & 6.83 & -2.376 & $.020^{*}$ \\
\hline Diploma UiTM & 37 & 64.92 & 5.69 & & \\
\hline
\end{tabular}

* Significance at the $5 \%$ level

Table 9. Regression results

\begin{tabular}{|c|c|c|c|c|c|c|}
\hline & Sign observed & Standardised beta & T-stats (sig.) & p- value & Tolerance & VIF \\
\hline (Constant) & & & 5.881 & 0.000 & & \\
\hline GENDER & + & 0.007 & 0.099 & 0.921 & 0.976 & 1.024 \\
\hline CGPA ENTRY & + & 0.331 & 4.450 & $0.000^{* * *}$ & 0.901 & 1.110 \\
\hline $\begin{array}{c}\text { ENGLISH PROFICIENCY } \\
\text { (MUET) }\end{array}$ & + & 0.342 & 4.593 & $0.000^{* * *}$ & 0.897 & 1.115 \\
\hline ENTRY QUALIFICATION & + & 0.264 & 3.600 & $0.000^{* * *}$ & 0.929 & 1.076 \\
\hline R square (\%) & 0.427 & & & & & \\
\hline Adjusted R Square & 0.407 & & & & & \\
\hline N & 120 & & & & & \\
\hline F-value & 21.412 & & & & & \\
\hline Sig. (2-tailed) & $0.000^{* * *}$ & & & & & \\
\hline
\end{tabular}

*** $1 \%$ significant level

Table 9 shows the impact of pre-university academic performance, entry qualification, English proficiency and gender on students' performance in the BAAF programme. The dependent variable is the final overall marks scored by students.

The results above show that the model is significant at the $1 \%$ level with $\mathrm{F}$-value of 21.412 . The adjusted $\mathrm{R}$ square is 0.407 , which indicates that the variables specified in the model can explain $40.7 \%$ of the variation in the BAAF academic performance. The independent variables of CGPA entry, entry qualification and English proficiency have a significant relationship with the performance of students at the BAAF programme. They are significant at the $1 \%$ level.

The results of multicollinearity test presented in Table 8 show no threat of multicollinearity. The CGPA entry of students is positively related to performance, indicating the higher the CGPA used for entry, the higher the performance of students in the Bachelor degree programme. The variable is highly significant at the $1 \%$ level $(\mathrm{t}=4.45$, $\mathrm{p}=0.000$ ). The standardised beta is 0.331 , indicating about $33 \%$ of the variation in the model is explained by CGPA entry. This result is consistent with Rajandran et al. (2014) who found that GPA of entry qualification for the students at the Faculty of Economics and Administration, University Malaya is a significant factor that affects the CGPA of the first-year student. The same result is documented by Byrne, M. and Flood, B (2008) who found that prior academic achievement is the most important variable in explaining the first year academic performance of accounting students at an Irish university.

The second independent variable of English proficiency is also positively related to the performance of BAAF students. The result is highly significant at the $1 \%$ level. The positive association between English proficiency and performance supports our hypothesis. English is expected to have a positive relationship with performance because the degree program is conducted entirely in English and as such, the ability to understand what is presented during academic lectures is an essential skill required by graduates. The positive influence of students' English proficiency and the performance of the BAAF program is, however, not consistent with another study in Malaysia. Ismail et al. (2017) in their study of factors contributing to the performance of Bachelor in Accounting (BACC) students at University Teknologi MARA found that English proficiency with similar measurement has no association with performance. The contradiction in result, perhaps 
explained by the fact that BAAF is a foreign degree qualification (Ireland) while BACC, on the other hand, is a local degree program In the non-English speaking country, even though BACC program is conducted entirely in English, the examinations perhaps focusing more on the content and not the language

The final independent variable, which is significantly associated with the performance of students is entry qualification. The positive association result indicates that graduates who enter the BAAF programme with Diploma qualification perform better than other groups of students. The result can be explained by the fact that Diploma students have covered more courses during their Diploma in comparison to STPM or matriculation students. The higher number of courses taken and the time spent during their two and a half or 3 years Diploma may have helped them in their analytical thinking that helps in the performance of their BAAF programme. The result is supported by Ali (2008), who found that entry qualification and school type were significantly related to the academic performance of the students in all three years of the general nursing Diploma programme.

Gender shows no association with the performance of students. The argument that female students in general work harder, attend classes regularly, and better control the balance between social life and academic life as compared to male students (Wally-Dima \& Mbekomize, 2013; Charles-Ogan, 2015) make them no different than their male counterpart in terms of academic performance at the BAAF program. Unlike the female, male students, on the other hand, may be using concentration, information processing and selecting main ideas strategies more, and getting better marks. This result is consistent with Amuda, Ali \& Durkwa (2016) who showed no significant differences between gender and academic performance for the senior secondary student in Maiduguri Metropolis for economic subjects. This result is also supported by Ambrose Okafor \& Egbon (2011) who concluded that there are no significant differences between gender and academic performance for undergraduate accounting students from Nigeria.

\section{Conclusions}

Since BAAF is a new programme offered by KPTM in collaboration with Dublin Business School (DBS), the study examined the factors that influence the academic performance of the BAAF students. From the analysis, the results show that the majority of the students enrolled for the BAAF programme are students with Diploma in accounting from either KPTM or UiTM. The results also show that the most significant number of students comes from Diploma from KPTM (48.3\%) followed by Diploma from UiTM (30.8\%) and the balance of $20.8 \%$ are students who entered the programme from STPM/Matriculation. Regarding academic performance, the results show that even though KPTM students enter the programme with higher CGPA than the other two groups of Diploma from UiTM and STPM/Matriculation students, they are not performing better than Diploma students from UiTM as shown by regression results.

The relationship between independent variables of gender, CGPA at admission, English proficiency and entry qualification was tested using regression analysis. The significant association between English, CGPA admission and entry qualification is consistent with the study expectation.

The results show that to produce graduates with high academic achievement; the university must choose the best candidate with good English proficiency. English proficiency seems to be powerful determinants of performance with the highest standardised beta of 0.34 , followed by CGPA admission and entry qualification. Therefore, it would be appropriate if BAAF admission policies not only focus on CGPA at the entrance but took the importance of English proficiency into consideration.

The university must also look at the possibility of promoting the programme to a larger group of Diploma students since the results show that they are performing better than matriculation or STPM students. The results are consistent with selection theory conjectures that all knowledge and knowledge growth are due to a process of cumulative blind variation and selection (Cziko, 1995). In this context, students' selection of programmes, and university selection criteria gives regard to various factors including pre-requisite knowledge as this is perceived to be contingent to future knowledge growth and performance (Aidoo-Buameh \& Ayagre, 2013).

The results of this study have several implications for university administrators and policymakers. It justifies increasing a higher level of English proficiency requirement on top of the minimum CGPA admission requirement. Currently, the university set quite a low minimum of a requirement for English. Secondly, since students with a diploma from UiTM performed better even with a lower admission CGPA. The results show that the same minimum CGPA for entry may not be fair for all students from a different higher institution. The minimum grade point required (min CGPA) for entry must consider the entire curriculum of the qualification used for entry. The results could also help the university in planning their promotional activities for this group of students, even while they are still in their Diploma program. Finally, the results could help future research in examining other factors contributing to academic performance.

\section{REFERENCES}

[1] Abdulrahman, M., \& Al-Mazrou, M. . (2008). Does academic performance in the premedical year predict the 
performance of the medical student in subsequent years? Journal of Family \& Community Medicine.

[2] Abisuga, A. O., Olanrewaju, D. O., \& Oyekanmi, O. O. (2015). Pre-Qualification Academic Requirement as Predictor of Academic Performance in a Building Technology Programme: A Case of Lagos State Polytechnic, Covenant Journal of Research in the Built Environment (CJRBE) Vol.3, No.1, 44-53.

[3] Aidoo-Buameh, J., \& Ayagre, P. (2013). The Effect of Entry Grades on Academic Performance of University Accounting Students: A case of Undergraduates of Central University College. Research Journal of Finance and Accounting, 4(7), 2222-2847.

[4] Ali, P. A. (2008). Admission criteria and subsequent academic performance of general nursing diploma students. Journal of the Pakistan Medical Association, 58(3), 128132.

[5] AlMously, N., Salem, R., \& AlHamdan, N. (2013). The impact of gender and English language on the academic performance of students: An experience from new Saudi medical school. Journal of Contemporary Medical Education, 1(2),

[6] Ambrose Okafor, C., \& Egbon, O. (2011). Academic Performance of Male versus Female Accounting Undergraduate Students: Evidence from Nigeria. Higher Education Studies, 1(1).

[7] Amuda, B. G., Ali, D. G., \& Durkwa, H. (2016). Gender Difference in Academic Performance in SSCE Economics Subject among Senior Secondary School Students in Maidaguri Metropolis, Borno State, Nigeria. American Journal of Educational Research, 4(3), 288-293.

[8] Buniyamin, N., Kassim, R. A., \& Mat, U. (2015). Correlation between MUET and academic performance of electrical engineering students. Ir.Uitm.Edu.My, 11(2), 111. Retrieved from http://ir.uitm.edu.my/id/eprint/15324

[9] Byrne, M. and Flood, B (2008). Examining the relationships among background variables and performance of the first year accounting students at an Irish University. Journal of Accounting Education, 26, 202-212.

[10] Charles-Ogan, G. (2015). Gender influences on study habits of mathematics students' achievement. International Journal of Academic Research and Reflection, 3(7), 24-28.

[11] Cziko, D. (1995). Without Miracles-Universal Selection Theory and The Second Darwinian Revolution. Massachusetts: Massachusetts Institute of Technology.

[12] Eze, T., Ezenwafor, J., \& Obidile, J. (2016). Effect of Gender on Students' Academic Performance and Retention in Financial Accounting in Technical Colleges. British Journal of Education, Society \& Behavioural Science, 18(4), $1-9$.

[13] Garkaz, M., Banimahd, B., \& Esmaeili, H. (2011b). Factors Affecting Accounting Students' Perf ormance: The Case Of Students At The Islamic Azad University. Procedia Social and Behavioral Sciences, 29, 122-128.

[14] Ghenghesh, P. (2014). The Relationship Between English Language Proficiency And Academic Performance of University Students - Should Academic Institutions Really be Concerned? International Journal of Applied Linguistics \& English Literature, 4(2).

[15] Islam, M. M. (2014b). Factors Influencing the Academic Performance of Undergraduate Students in Sultan Qaboos University in Oman. Journal of Emerging Trends in Educational Research and Policy Studies, 5(4), 396-404.

[16] Ismail, N,, Mat Dangi, M.R., Ali, N., Abdul Rasit, Z. Entry Grade and Bachelor of Accountancy Graduate performance: a Case of admission with Accounting Diploma. 8th International Conference on University Learning and Teaching (InCULT 2016).

[17] James, G., Reem, A., Shyamala, H., \& Sharada, R. (2014). Cumulative grade point average as a tangible predictor of academic achievement: A retrospective cross-sectional study. JETHS, Vol 1, issue 2, 7-12.

[18] Jayanthi, S. V., Balakrishnan, S., Lim, A., Ching, S., Aaqilah, N., Latiff, A., \& Nasirudeen, A. M. A. (2014). Factors Contributing to Academic Performance of Students in a Tertiary Institution in Singapore. American Journal of Educational Research, 2(9), 752-758.

[19] Kukreja, G., Habib, M., \& Aali, A. (2013). Journal of Emerging Issues in Economics, Finance and Banking (JEIEFB) The Determinants of Students' Performance in Introductory Accounting Courses: Evidence from Kingdom of Bahrain Journal of Emerging Issues in Economics, Finance and Banking (JEIEFB). An Online International Monthly Journal, (313), 2306-2367.

[20] Kumar, P. (2014). Effect of Proficiency in English Language on Academic Performance of Post Graduate Management Students of Marathwada Region (Maharashtra), Indialn. IOSR Journal of Business and Management (IOSR-JBM), 16(5), 10-16.

[21] Kyei, L., \& Apam, B. (2011). Some gender differences in performance in senior high mathematics examinations in mixed high schools. American Journal of Social and Managementt Sciences, 2(4), 348-355.

[22] Ladan, S. ., Adeshina, T. ., \& Udoh, A.. (2015). Relationship between Accounting Entry Grades and Students , Performance in Accounts in Federal Colleges of Education in North-West Geo-Political Zone , Nigeria. International Journal of Academic Research in Education and Review, 3(August), 197-203.

[23] Millie, R., Racca, A. B., \& Lasaten, R. C. S. (2016). English Language Proficiency and Academic Performance of Philippine Science High School Students, International Journal of Languages, Literature and Linguistics, Vol. 2, No. 2, 44-49.

[24] Mohd Nopiah, Z., Ismail, N. A., Khatimin, N., Abdullah, S., \& Mustafa, M. M. (2011). MUET score and loadings hour : An analysis on the relationship towards academic performance. Procedia - Social and Behavioral Sciences, 18, 103-109.

[25] Othman, J., \& Nordin, A. B. (2013a). MUET As A Predictor Of Academic Achievement In ESL Teacher Education. Journal of Language Studies, 13(February), 99-111.

[26] Rahmat, N., Min, L. Si., Sungif, N. A. M., \& Yusup, F. N. M. (2015). English Language Proficiency Tests and Academic Achievement: A Study on the Malaysian University English 
Test as a Predictor of Technical Programme Undergraduates Academic Achieve ment. Advances in Language and Literary Studies, 6(1), 2-7.

[27] Rajandran, K., Hee, T., Kanawarthy, S., Soon, L. ., Kamaludin, H., \& Khezrimotlagh, D. (2014). Factors Affecting First Year Undergraduate Students Academic Performance. Journal of Economics, Business and Management, 1(2), 54-56.

[28] Rethinasamy, S., \& Chuah, K. M. (2011). The Malaysian university English test (MUET) and its use for placement purposes: A predictive validity study. Electronic Journal of Foreign Language Teaching, 8(2), 234-245.

[29] Sahragard, R., Baharloo, A., Mohammad, S., \& Soozandehfar, A. (2011). A Closer Look at the Relationship between Academic Achievement and Language Proficiency among Iranian EFL Students. Theory and Practice in Language Studies, 1(12), 1740-1748.

[30] Sam, L. (2016). Gender Differences in Academic Performance of Financial Accounting Students in Selected Senior High Schools in the Central Region of Ghana. Advances in Social Sciences Research Journal, 3(8), 40-46.

[31] Sheard, M. (2009). Hardiness commitment, gender, and age differentiate university academic performance. British Journal of Educational Psychology, 79(1), 189-204.

[32] Soto, J. G., \& Anand, S. (2009). Factors influencing academic performance of students enrolled in a lower division Cell Biology core course. Journal of the Scholarship of Teaching and Learning, 9(1), 64-80.

[33] Tho, L (1994). Some evidence on the determinants of students' performance in the University of Malaya introductory accounting course. Accounting Education 2(4), 331-340.

[34] Wally-Dima, L., \& Mbekomize, C. J. (2013). Causes of gender differences in accounting performance: Students' perspective. International Education Studies. Vol 6, No 10, $13-26$

[35] Woodrow, L. (2006). Academic Success of International Postgraduate Education Students and the Role of English Proficiency, University of Sydney Papers in TESOL, 1, 51-70.,

[36] Yen, D., \& Kuzma, J. (2009). Higher IELTS Score, Higher Academic Performance? The Validity of IELTS in Predicting the Academic Performance of Chinese Students. Worcester Journal of Learning and Teaching, 3, 1-7.

[37] Zainal, R., Yahya, R., \& Abdul Rahman, K. (2014). Influences of gender on academic achievement of Fiber Optic Communication System: An experience of Politeknik Merlimau Melaka \n. IOSR Journal of Humanities and Social Science (IOSR-JHSS), 19(8), 108-111. 